\title{
THE EXCRETION OF PORPHYRIN IN REFRACTORY AND APLASTIC ANEMIA
}

\author{
BY K. DOBRINER, C. P. RHOADS, AND L. E. HUMMEL \\ (From the Hospital of the Rockefeller Institute for Medical Research, New York City)
}

(Received for publication October 18, 1937)

Technical procedures which have been developed for quantitative measurements of the rate of excretion of the porphyrins have advanced the knowledge of the fundamental nature of certain anemic states. By such studies the disorders of hematopoiesis may be divided into two major groups on a pathological-physiological basis. In one group the metabolism of the pigments is quantitatively increased but is normal in type. Pernicious anemia, congenital hemolytic jaundice, and the anemia caused by phenylhydrazine are all of this variety $(1,2,3,4,5)$. In a second group, however, a qualitative as well as a quantitative deviation from the normal metabolism of pigments exists. The anemia of lead $(6,7,8)$ and salvarsan poisoning (9), and of certain hepatic cirrhoses, notably hemachromatosis, are of this type $(1,10)$.

Recent advances in the treatment of pernicious anemia and the anemias of a deficiency of iron and copper have made prominent a group of blood dyscrasias which does not respond to the administration of liver extract or of iron. Cases of this type which are apparently primary are termed aplastic, aregenerative or achrestic anemia, and compose a group of general as well as of physiological interest.

The cause of primary aplastic anemia is obscure in most instances, although certain cases are encountered in which exposure to benzol, gold, or arsphenamine seems to have been etiological. Histological study of the hematopoietic bone marrow in these toxic cases shows no consistent difference from the lesions in patients clinically similar but who give no history of exposure to potentially toxic compounds.

Aplastic anemia is, then, therapeutically unlike pernicious anemia or the microcytic anemias, and certain cases seem to be toxic in origin. Studies of the metabolism of the pigments in cases of aplastic anemia should establish conclusively whether the underlying physiological disturbance is like that of the deficiency or of the toxic group. In the course of a study of refractory anemia, detailed observations of the metabolism of pigments have been made in six patients. Studies of one such case have been reported by Brugsch (11). The cases were selected to represent as closely as possible the different subgroups into which aplastic anemia may be divided (12).

To render the rationale of this study and the validity of the results intelligible, the brief review by Dobriner and Rhoads of the chemistry of the porphyrins should be consulted (13).

\section{METHODS}

The chemical and physical procedures which have been employed for the qualitative and the quantitative determinations of the excretion of porphyrins are those which have been reported previously $(1,2)$. The total outputs of urine and stools have been collected with toluol as a preservative for periods of three days and aliquot fractions analyzed. Determinations of the content of urobilin have been made by the method of Watson (14). The excretion of porphyrin is expressed in micrograms for the daily average of each 3-day period, the excretion of urobilin in milligrams. In the figures, the average levels of daily excretion are presented for the various periods of treatment.

Case 1 (H. D.) (Figure 1). A 66-year old female with anemia of 3 years' duration. The past history was irrelevant except for a thyroidectomy for hyperthyroidism 8 years previously. Blood transfusions had been given at intervals of 30 days and liver extract administered orally and parenterally without effect. Basal metabolic rate was -6 . Throughout the period of observation the erythrocytes varied from 900,000 to $1,200,000$, the hemoglobin from 15 to 23 per cent $\left(100\right.$ grams $=O_{2}$ combining capacity 19.6 volumes per cent), and the leukocytes from 1,600 to 3,400 . The differential leukocyte count was not remarkable. The reticulocytes were always less than 1 per cent. The platelets numbered 290,000 , and the resistance of the erythrocytes to hypotonic salt solution was normal. A biopsy of the sternal bone 
marrow showed practically complete aplasia of the hematopoietic tissue, only scattered groups of primitive cells remaining.
The patient was then transfused and the average output of coproporphyrin for the second 9-day period rose to 368 micrograms, of which 114 were in the urine. This
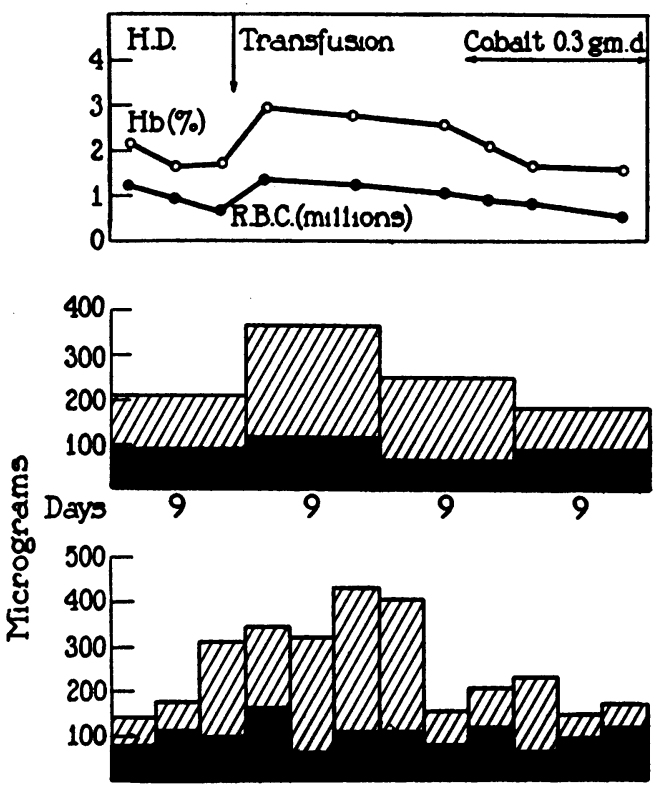

Coproporphyrin

Average daity output

in 9-day periods

UDFecal

Urinary

Fig. 1. Coproporphyrin Excretion in Case 1

Quantitative determinations of the excretion of porphyrin were carried out for a period of 36 days, terminating 2 weeks before death. During a 9-day control period the total coproporphyrin output was 210 micrograms per day, and of this 89 micrograms were in the urine and the remainder in the feces. These levels are appreciably lower than are the normal levels of excretion in adults. increase may possibly be due to the transfusion, for in the subsequent two 9-day periods the total output of coproporphyrin averaged 253 and 182 micrograms per day respectively. One determination of urobilin averaged $83 \mathrm{mgm}$. per day for a 3-day period, a level distinctly lower than normal.

The excreted coproporphyrin was identified by the

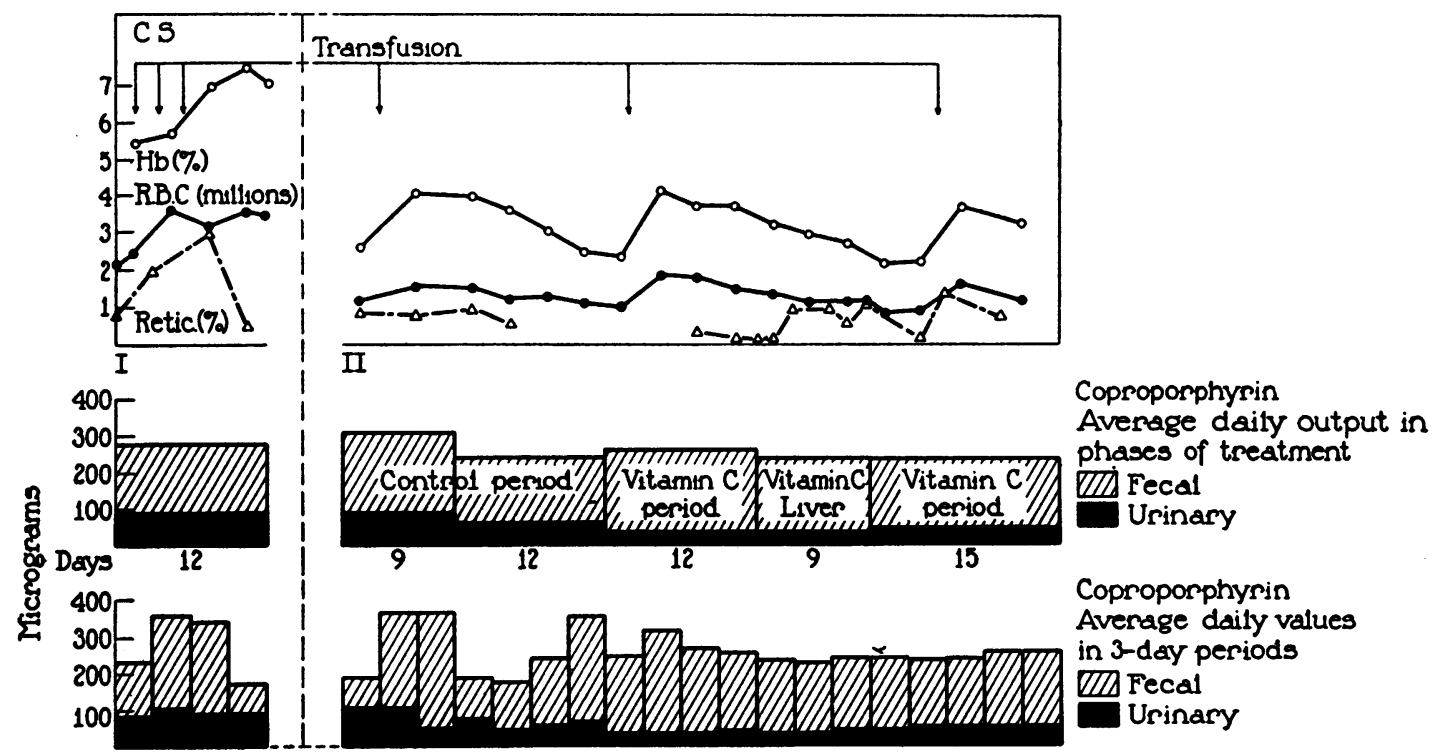

Fig. 2. Coproporphyrin Excretton in CASE 2 
determinations of melting point as coproporphyrin I $\left(235^{\circ}\right.$ C.). The presence of Type III coproporphyrin $u$ as suggested by the chemical reactions but could not be proved by determinations of the melting point because of lack of material. Besides coproporphyrin, the stools contained small amounts of protoporphyrin and deuteroporphyrin.

Case 2 (C. S.) 2 (Figure 2). A 54-year old teacher with anemia of 3 years' duration. The past history cells of a more adult type than primitive, endothelial or blast forms were present.

During the first period of observation, the patient was transfused three times and received various forms of treatment. The totat output of coproporphyrin averaged 278 micrograms per day; of this, 92 micrograms were in the urine. Small amounts of protoporphyrin and deuteroporphyrin were present in the feces. The output of coproporphyrin increased somewhat after the transfusions.
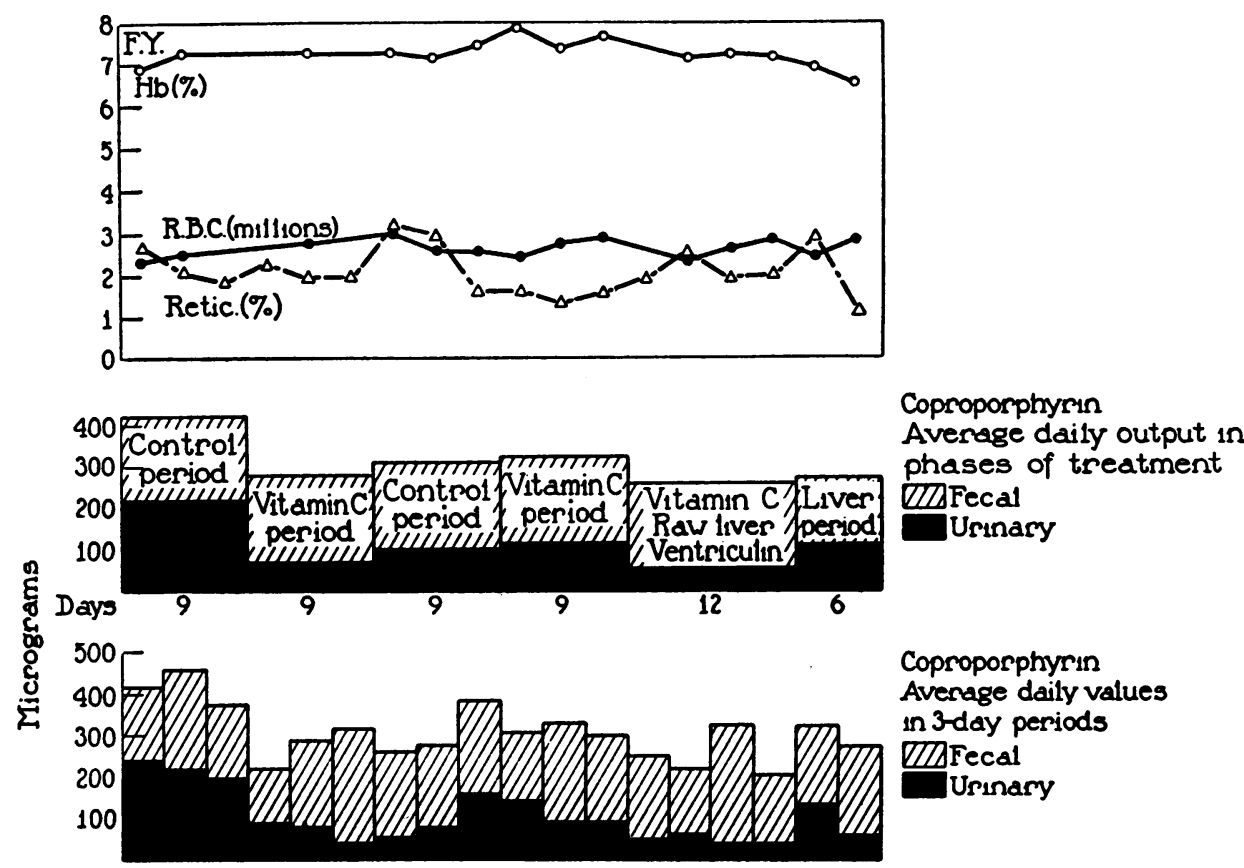

Fig. 3. Coproporphyrin Excretion in Case 3

revealed that she had dyed her hair regularly for 15 years with a paraphenylendiamine compound. Over a period of seven and one-half months she had received eleven blood transfusions and various forms of liver extract without effect. On admission the red blood cells numbered $1,230,000$, the mean corpuscular volume 100 , the hemoglobin was 35 per cent, leukocytes 800, the reticulocytes 0.9 per cent, platelets 38,000 per $\mathrm{mm} .^{3}$, and the fragility of the red blood cells was normal. Free hydrochloric acid was present in the gastric juice, and tests of the ability of the liver to excrete bilirubin and to convert sodium benzoate to hippuric acid showed no abnormality.

A biopsy of the sternal bone marrow revealed a moderately cellular marrow with a very marked lack of maturation of the hematopoietic cells. Practically no

2 The patient C. S. was observed both at The Strong Memorial Hospital in Rochester, New York, and at The Hospital of the Rockefeller Institute, and the authors wish to express their appreciation of the assistance of Dr. W. S. McCann in this matter.
The second period of observation was of 54 days. During the first 9-day control period the total output of coproporphyrin averaged 310 micrograms per day, of which 87 were in the urine. During this time the patient was transfused, and the excretion of coproporphyrin increased. Because of this fact a second control period of 12 days was used, during which the coproporphyrin averaged 243 micrograms per day, of which 65 were in the urine. The latter value is appreciably lower than normal. During the remainder of the study the patient was transfused several times, treated with vitamin $C$ and with liver extract, without significant change in the excretion of coproporphyrin. The urobilin averaged 133 mgm. per day for a 3-day period.

The excreted porphyrin was identified by the melting point as coproporphyrin I $\left(222^{\circ}\right.$ C.) and small amounts of coproporphyrin III $\left(143^{\circ}\right.$ C.).

Case 3 (F. Y.) (Figure 3). A 30-year old housewife with anemia of 10 years' duration. When 12 years of age she developed a brown mottling of the skin of the neck and upper chest. A severe toxemia of pregnancy ending with a miscarriage occurred at 20 . At this time the hemoglobin was 27 per cent and transfusions were 
given followed by reactions. The hemoglobin rose gradually to 65 per cent, but chronic anemia persisted for several years until the occurrence of a second pregnancy 18 months before admission, when there was an exacerbation and the hemoglobin fell to 33 per cent. The pregnancy was terminated and the patient improved. Another pregnancy one year before admission followed a histological examination of the tissue revealed a moderately cellular structure with a well defined predominance of young cell forms. No suggestion of leukemia was seen. The hematopoietic islands were somewhat larger than normal and a diffuse infiltration of immature cells was present.

During a 9-day control period the output of copro-
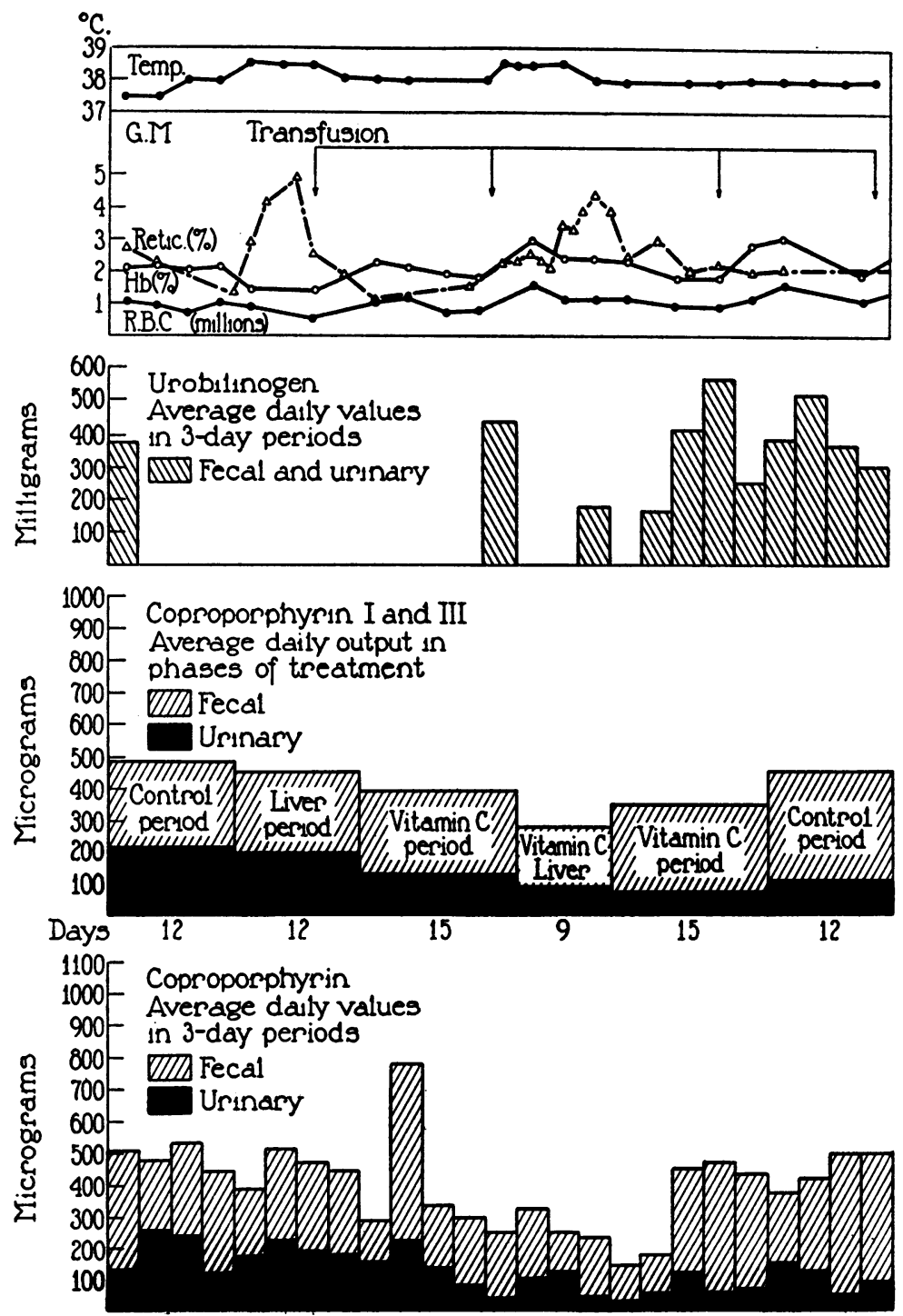

Fig. 4. Coproporphyrin aNd Urobilinogen Excretion in Case 4

similar course. On admission the erythrocytes numbered $2,400,000$, the hemoglobin was 70 per cent, the mean corpuscular volume 116, the white blood cells 2,250, the reticulocytes 2.5 per cent and the platelets 55,000 . The icteric index was 5 , and the fragility of the erythrocytes was normal. Tests of liver function were normal. The liver and spleen were not enlarged.

A biopsy of the sternal bone marrow was made and porphyrin averaged 417 micrograms per day, of which 220 were in the urine. In the second 9-day period the patient was treated with 1 gram of vitamin $C$ daily, and the total coproporphyrin fell to 277 with a marked drop in the porphyrins of the urine to 68 . The excretion in the feces did not change. In the subsequent 9-day periods, the first untreated, and the second a vitamin $\mathrm{C}$ period, the total excretion of coproporphyrin did not 
change appreciably, although the porphyrin in the urine rose to 100 and 110 micrograms respectively. During the next 12 days of observation the patient received vitamin $C$, raw liver, and ventriculin. The average daily output of coproporphyrin decreased to 250 micrograms, of which 47 were in the urine. During the final 6 days of observation the patient received liver extract intravenously, and the total average daily output of coproporphyrin was 262 micrograms as compared to 250 in the previous period, but the porphyrin in the urine increased somewhat.

The excretion of urobilin averaged $99 \mathrm{mgm}$. daily.

Small amounts of protoporphyrin were present in the feces. The coproporphyrin excreted was identified as coproporphyrin I, melting point $225^{\circ}$. C., and coproporphyrin III by a melting point of $127^{\circ} \mathrm{C}$.

Case 4 (G. M.) (Figure 4). A 34-year old ship steward was admitted with anemia of one year's duration. He had had malaria in 1917 and 9 years prior to admission he developed psoriasis, which was treated by X-ray therapy from 1930 to 1935 . One year after the last treatment he developed fever and weakness and was admitted to another hospital with a severe anemia which was refractory to treatment. Physical examination on admission to this institution was not remarkable. The erythrocytes numbered $1,640,000$, the hemoglobin was 30 per cent, the mean corpuscular volume 84 , the platelets 136,000 , and the reticulocytes 5 per cent. Free hydrochloric acid was present in the gastric juice, tests of liver function were normal, the icteric index was 6 . The fragility of the erythrocytes was normal. The patient had received eleven transfusions.

A biopsy of the sternal bone marrow revealed a normal degree of cellularity, and active hematopoiesis was apparently proceeding. No marked interference with maturation of hematopoietic cells was apparent.

Quantitative determinations of the excretion of coproporphyrin were made for a period of 75 days. Besides coproporphyrin relatively large amounts of protoporphyrin and small amounts of deuteroporphyrin were present in the feces.

During a 12-day control period the total excretion of coproporphyrin averaged 492 micrograms, and of this 212 were in the urine, both definitely elevated values. The urobilin excretion averaged $380 \mathrm{mgm}$. per day, a high level. During the subsequent 12-day period liver extract was given intramuscularly without significant effect on the excretion of porphyrin. For the next 15 days the patient received $1 \mathrm{gram}$ of ascorbic acid by mouth daily. The excretion of coproporphyrin in the urine decreased to an average of 126 micrograms per day, and the total output of coproporphyrin to 395 micrograms. The output of coproporphyrin in the feces remained constant, and the observed decrease in the total output was consequent to the decreased amount in the urine. Except for one high value, the levels during this period were lower than in the control and in the previous liver period. In a subsequent 9-day period concentrated liver extract and 1 gram of vitamin $C$ were administered daily. The average output for this period decreased to 275 micrograms, of which 93 were in the urine, levels which are distinctly lower than normal. This period was followed by a 15-day period during which 1 gram of vitamin $C$ alone was administered daily. The total output of coproporphyrin rose to average 343 micrograms per day. The rise was principally in the porphyrin of the feces, the urinary coproporphyrin averaging 68 micrograms. The final 12 days of observation were utilized as an untreated control period and the total excretion of coproporphyrin increased again to an average of 455 micrograms per day, approaching the values of the first control period.

During the period of study the patient was transfused 4 times without significant change in the rate of excretion of coproporphyrin.

The levels of the excretion of urobilin following liver extract and vitamin $\mathrm{C}$ decreased, and following the termination of therapy, increased to the level before treatment.

The excreted coproporphyrin was proved to be a mixture of coproporphyrin I $\left(233^{\circ}\right.$ C. $)$ and III $\left(138 / 165^{\circ}\right.$ C.) by melting point determinations.

Case 5 (W.G.) (Figure 5). A 26-year old male was admitted with severe anemia of 6 years' duration. There
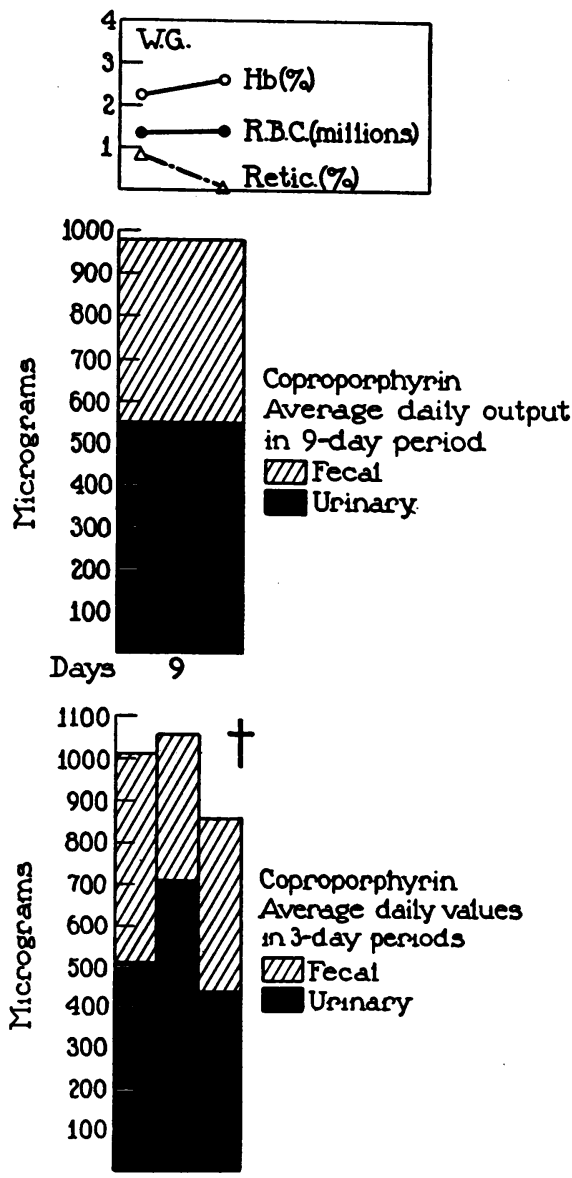

Fig. 5. Coproporphyrin Excretion in Case 5 
was a bilateral orchidectomy in 1924 for one undescended and one strangulated testicle, and in 1931 a severe refractory anemia developed. Since November 1935 the patient had received repeated transfusions. On admission there was brown pigmentation of the skin, particularly on the exposed areas. The liver and spleen were enlarged.

A biopsy of sternal bone marrow, when studied histologically, revealed an active, cellular tissue crowded with hematopoietic cells in all stages of development. Both are approximately three times normal. The urobilin averaged 273 per day for a period of 3 days.

The excreted porphyrin was proved to be a mixture of coproporphyrin I $\left(232^{\circ}\right.$ C. $)$ and III $\left(140^{\circ}\right.$ C. $)$ by determinations of the melting points.

Case 6 (A. C.) (Figure 6). A single male photographic worker of 22 with anemia of 2 months' duration. In his work this patient was exposed to hydroquinone and other potentially toxic agents. Onset with epistaxis, weakness, purpura, and pallor. Six transfusions were
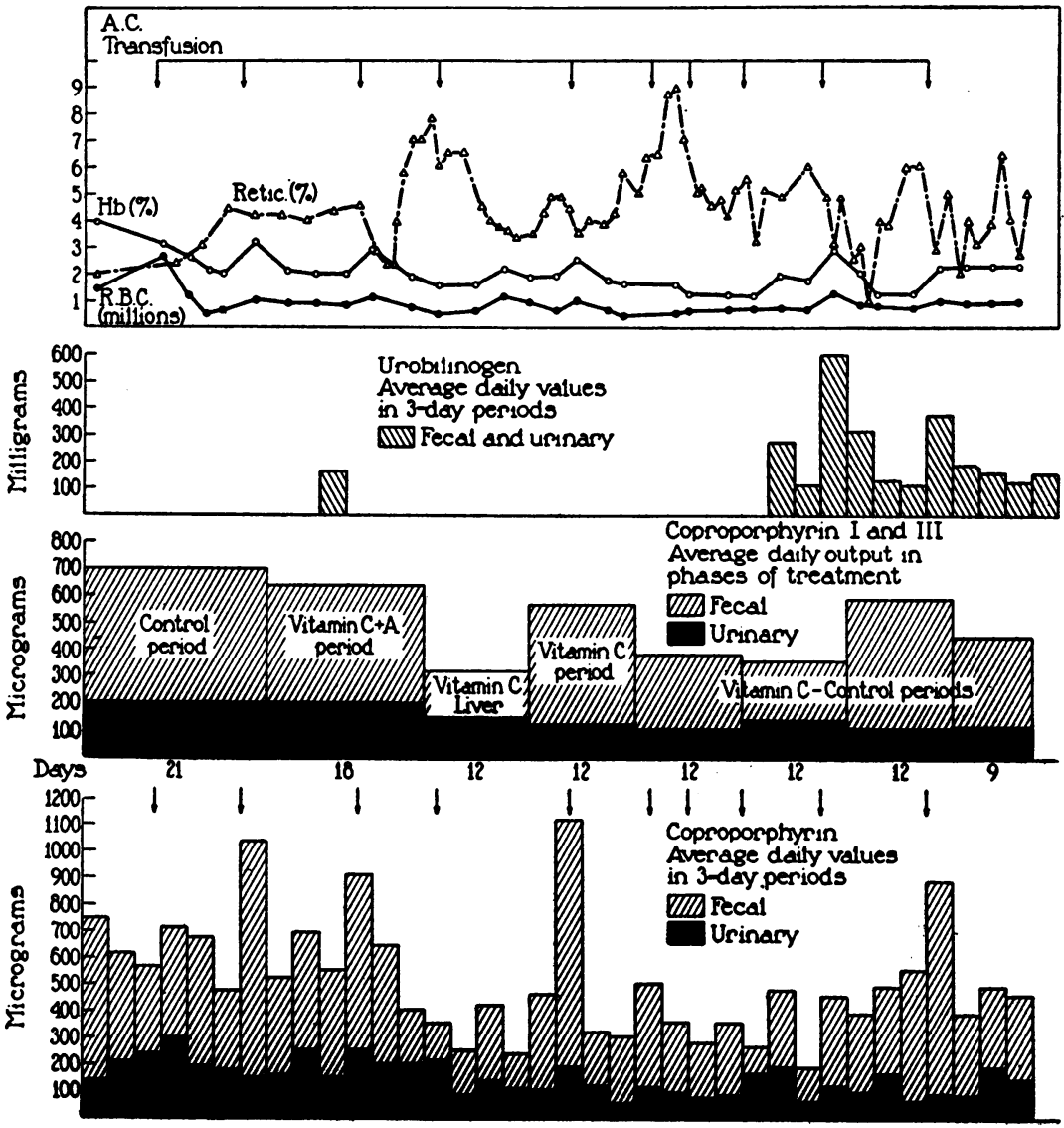

Fig. 6. Coproporphyrin and Urobilinogen Excretion in Case 6

the erythropoietic and the myelopoietic series were represented in the hyperplasia. No suggestion of leukemia was seen.

The erythrocytes numbered $2,010,000$, and the hemoglobin 40 per cent. The leukocytes were 2,400 , the platelets 250,000 , and the reticulocytes 0.8 per cent. The fragility of the erythrocytes was normal. In spite of blood transfusions the patient became rapidly worse, the erythrocytes decreasing to $1,420,000$ and the hemoglobin to 27 per cent. The leukocytes fell to 1,300 , and no reticulocytes were demonstrable.

The output of coproporphyrin averaged 978 micrograms per day, and of this $\mathbf{5 5 0}$ were in the urine. These levels given before admission, also liver extract intramuscularly and iron without effect. Erythrocytes 1,200,000, hemoglobin 25 per cent, leukocytes 4,150, mean corpuscular volume 116, reticulocytes 4 per cent, platelets 166,000 per mm. $^{3}$ Fragility of the erythrocytes was normal. Free hydrochloric acid was present in the gastric juice and tests of liver function gave normal values.

Biopsy of the sternal bone marrow showed practically complete aplasia of the hematopoietic tissue.

During a control period of 21 days the patient excreted daily an average of 694 micrograms of coproporphyrin, of which 201 were contained in the urine. In the subsequent 18 days he received 2 grams of crystalline 
TABLE I

The rate of excretion of coproporphyrin and urobilinogen, the blood levels, and the type of the bone marrow in the control period as well as the type of coproporphyrin excreted

\begin{tabular}{|c|c|c|c|c|c|c|c|c|c|c|}
\hline \multirow{2}{*}{ Case number } & \multirow{2}{*}{$\begin{array}{l}\text { Control } \\
\text { period }\end{array}$} & \multicolumn{3}{|c|}{$\begin{array}{l}\text { Average daily } \\
\text { coproporphyrin excretion }\end{array}$} & \multirow{2}{*}{$\begin{array}{c}\text { Average daily } \\
\text { urobilinogen } \\
\text { excretion }\end{array}$} & \multirow{2}{*}{$\begin{array}{l}\text { Red } \\
\text { blood } \\
\text { cells }\end{array}$} & \multirow{2}{*}{ Hemoglobin } & \multirow{2}{*}{$\begin{array}{l}\text { White } \\
\text { blood } \\
\text { cells }\end{array}$} & \multirow{2}{*}{ Bone marrow } & \multirow{2}{*}{$\begin{array}{l}\text { Type of } \\
\text { coproporphyrin } \\
\text { excreted }\end{array}$} \\
\hline & & Urine & Feces & Total & & & & & & \\
\hline $\begin{array}{l}\text { 1. H. D... } \\
\text { 2. C. S.... } \\
\text { 3. F. Y.... } \\
\text { 4. G. M... }\end{array}$ & $\begin{array}{c}\text { days } \\
9 \\
12 \\
9 \\
12\end{array}$ & \begin{tabular}{|c|} 
micrograms \\
89 \\
65 \\
220 \\
212
\end{tabular} & \begin{tabular}{|c|} 
micrograms \\
122 \\
178 \\
197 \\
280
\end{tabular} & \begin{tabular}{|c|} 
micrograms \\
210 \\
243 \\
417 \\
492
\end{tabular} & $\begin{array}{c}\text { mgm. } \\
83 \\
133 \\
99 \\
370-450\end{array}$ & $\begin{array}{c}\text { millions } \\
1.100 \\
1.230 \\
2.400 \\
1.110\end{array}$ & $\begin{array}{c}\text { per cent } \\
21 \\
35 \\
70 \\
22\end{array}$ & $\begin{array}{r}1000 \\
800 \\
2250 \\
950\end{array}$ & $\begin{array}{l}\text { Hypoplastic } \\
\text { Hypoplastic } \\
\text { Immature } \\
\text { Normally }\end{array}$ & $\begin{array}{l}\text { I (and III ?) } \\
\text { I and III } \\
\text { I (and III ?) } \\
\text { I and III }\end{array}$ \\
\hline $\begin{array}{l}\text { 5. W. G... } \\
\text { 6. A. C.... }\end{array}$ & $\begin{array}{r}9 \\
21\end{array}$ & $\begin{array}{l}550 \\
201\end{array}$ & $\begin{array}{l}428 \\
493\end{array}$ & $\begin{array}{l}978 \\
694\end{array}$ & $\begin{array}{c}273 \\
128-165\end{array}$ & $\begin{array}{l}1.42 \\
1.440\end{array}$ & $\begin{array}{l}27 \\
39\end{array}$ & $\begin{array}{l}1300 \\
2500\end{array}$ & $\begin{array}{l}\text { Cellular } \\
\text { Hyperplastic } \\
\text { Hypoplastic }\end{array}$ & $\begin{array}{l}\text { I and III } \\
\text { I and III }\end{array}$ \\
\hline Normals & 9 & $87-123$ & 205-274 & $306-376$ & 150 & & & & & I \\
\hline
\end{tabular}

vitamin C daily by mouth, but no effect on the excretion of porphyrin was detectable since the daily average was 627 micrograms, of which 208 were in the urine. It is striking that in the periods of 3 days each, which followed 3 transfusions of blood with febrile reaction, there was a distinct increase in the output of coproporphyrin. During the next 12 days $5 \mathrm{cc}$. of concentrated liver extract (Lederle and Co.) was administered each day intramuscularly. This was accompanied by a sharp decrease in the excretion of coproporphyrin to a daily average of 320 micrograms, of which 141 were in the urine. In 5 subsequent control periods of 12 days each with vitamin $\mathrm{C}$ the excretion of coproporphyrin was increased but was still definitely less than in the original control period. During this time the increased output of coproporphyrin following transfusion is once more apparent.

An increased amount of protoporphyrin was present in the stools and also a small amount of deuteroporphyrin.

The excreted coproporphyrin was identified as a mixture of coproporphyrin I $\left(232^{\circ} \mathrm{C}\right.$.) and coproporphyrin III $\left(142 / 165^{\circ} \mathrm{C}\right.$. $)$ by determination of the melting point.

\section{DISCUSSION}

The quantitative and qualitative excretions of coproporphyrin are summarized in Table I, together with the levels of the excretion of urobilin, and the hematological and bone marrow findings.

Four cases (Numbers 2, 4, 5, and 6) showed a mixed excretion of Type I and Type III coproporphyrin. In 2 cases (Numbers 1 and 3), although coproporphyrin III was not definitely identified, its presence was indicated. Since only inaccurate quantitative methods for the separation of the isomers are available, the quantitative relations between coproporphyrin I and III cannot be determined. Approximately estimated, about one-fifth of the excreted coproporphyrin in Cases 4, 5, and 6 was coproporphyrin III. In
Cases 2 and 3 probably less than one-tenth of the total excretion was coproporphyrin III.

The simultaneous excretion of Types I and III coproporphyrin in aplastic anemia indicates that the metabolism of pigment in that condition is different from any which has been observed in normal individuals, in hemolytic jaundice, or in pernicious anemia. Furthermore, the disturbance in aplastic anemia differs from that observed in congenital porphyria where mass excretion of Type I coproporphyrin reverses the normal ratio between the construction rate of Type I and Type III porphyrins. The mixed excretion does, however, bear some similarity to that which has been reported in certain diseases of the liver, such as pigment cirrhosis and melanosarcoma, in lead and salvarsan intoxication, and in the conditions classified as acute and chronic porphyria.

The excretion of Type III coproporphyrin indicates a faulty metabolism of pigment, and results from either faulty construction or destruction of the respiratory pigments in any stage of their genesis or breakdown. Whether either or both of these theoretical possibilities is responsible has not yet been determined.

Of the six cases studied, three showed a hyperplastic and three a hypoplastic bone marrow. The three patients with hyperplastic marrow showed an increased excretion of coproporphyrin. Of the cases with hypoplastic marrow two showed a decreased excretion, and one a marked increase. No explanation of the last case is at hand. In only one case was an apparently definite effect of vitamin $\mathrm{C}$ on the excretion of porphyrin noted. 
In this instance the decreased excretion of porphyrin was due to a decrease in the coproporphyrin of the urine alone. In Cases 4 and 6 the excretion of coproporphyrin decreased following liver therapy, and was further decreased in Case 4 when liver and vitamin $C$ were used together, although vitamin $\mathrm{C}$ alone produced little or no effect. The mechanism of these possible changes is not known. However, unpublished studies of congenital porphyria have shown that both liver (15) and vitamin C (16) have some effect on disturbance of pigment metabolism in this disease.

\section{SUMMARY AND CONCLUSIONS}

1. In 4 of 6 cases of aplastic anemia studied, a mixture of Type I and Type III coproporphyrins was excreted as ascertained by determination of the melting points of the crystalline pigments. In 2 other cases the presence of the Type III compound was indicated but not proven because of lack of material.

2. The pathological excretion of Type III porphyrins suggests that aplastic anemia results from an intoxication.

\section{BIBLIOGRAPHY}

1. Dobriner, $\mathrm{K}$., Urinary porphyrins in disease. J. Biol. Chem., 1936, 113, 1.

Porphyrin excretion in the feces in normal and pathological conditions. J. Biol. Chem., 1937, 120, 115.

2. Dobriner, K., Strain, W. H., and Localio, S. A., I. Quantitative measurement of coproporphyrin and total coproporphyrin I excretion in normals. Proc. Soc. Exper. Biol. and Med., 1937, 36, 752.

3. Dobriner, K., Strain, W. H., Localio, S. A., Keutmann, H., and Stephens, D. I., II. Coproporphyrin I metabolism and hematopoietic activity. Proc. Soc. Exper. Biol. and Med., 1937, 36, 755.
4. Dobriner, K., Excretion of porphyrin by dogs. Proc. Soc. Exper. Biol. and Med., 1937, 36, 757.

5. Watson, C. J., Concerning the naturally occurring porphyrins. III. The isolation of coproporphyrin I from the feces of untreated cases of pernicious anemia. J. Clin. Invest., 1935, 14, 116.

V. Porphyrins of the feces. J. Clin. Invest., 1937, 16, 383.

6. Grotepass, W., Zur Kenntnis des im Harn auftretenden Porphyrins bei Bleivergiftung. Ztschr. f. physiol. Chem., 1932, 205, 193.

7. Watson, C. J., Concerning the naturally occurring porphyrins. IV. The urinary porphyrin in lead poisoning as contrasted with that excreted normally and in other diseases. J. Clin. Invest., 1936, 15, 327.

8. Vigliani, E. C., and Waldenström, J., Untersuchungen über die Porphyrine beim Saturnismus. Deutsches Arch. f. klin. Med., 1937, 180, 182.

9. Schreus, H. Th., Welches isomere Koproporphyrin wird bei Blutzerfall ausgeschieden? Klin. Wchnschr., 1935, 14, 1717.

10. Vigliani, E. C., and Libowitzky, H., Uber Porphyrine im Harn und im Kot. Klin. Wchnschr., 1937, 16, 1243.

11. Brugsch, J. T., Untersuchungen des quantitativen Porphyrinstoff wechels beim gesunden und kranken Menschen. Ztschr. f. d. ges. exper. Med., 1935, 95, 482.

12. Rhoads, C. P., and Miller, D. K., Study of the bone marrow in aplastic anemia. Am. J. Path. (Proc.), 1934, 10, 679.

13. Dobriner, K., and Rhoads, C. P., The metabolism of blood pigments in pernicious anemia. J. Clin. Invest., 1938, 17, 95.

14. Watson, C. J., The average daily elimination of urobilinogen in health and in disease, with special reference to pernicious anemia. Standardization of method based on mesobilirubinogen. Arch. Int. Med., 1931, 47, 698.

15. Dobriner, K., Strain, W. H., Localio, S. A., and Guild, H. Unpublished work.

16. Dobriner, K., and Guild, H., Unpublished work. 